Meta

Journal des traducteurs

Translators' Journal

\title{
Teaching Subtitling Routines
}

\section{Herman Brondeel}

Volume 39, numéro 1, mars 1994

La traduction et l'interprétation dans la Belgique multilingue

URI : https://id.erudit.org/iderudit/002150ar

DOI : https://doi.org/10.7202/002150ar

Aller au sommaire du numéro

Éditeur(s)

Les Presses de l'Université de Montréal

ISSN

0026-0452 (imprimé)

1492-1421 (numérique)

Découvrir la revue

Citer cet article

Brondeel, H. (1994). Teaching Subtitling Routines. Meta, 39(1), 26-33.

https://doi.org/10.7202/002150ar

\section{Résumé de l'article}

Le Provinciale Hogeschool voor Vertalers en Tolken de la Flandre Orientale a élaboré et mis sur pied un cours de " sous-titrage ». On décrit, dans cet article, les stratégies pédagogiques utilisées pour l'enseignement du sous-titrage ainsi que les différentes composantes de 


\title{
TEACHING SUBTITLING ROUTINES
}

\author{
HERMAN BRONDEEL \\ Provinciale Hogeschool voor Vertalers en Tolken, Ghent, Belgium
}

\begin{abstract}
Résumé
Le Provinciale Hogeschool voor Vertalers en Tolken de la Flandre Orientale a élaboré et mis sur pied un cours de «sous-titrage». On décrit, dans cet article, les stratégies pédagogiques utilisées pour l'enseignement du sous-titrage ainsi que les différentes composantes de ce cours.
\end{abstract}

\section{A SINGLE-STANDARD APPROACH}

We started with home-made experimental software and a small $\mathrm{BBC}$ micro, which has now been replaced with four subtitling systems that run on ScanTitling software. We copy VHS and U-matic material on VHS videotapes while generating VITC time-codes of our own by means of a Fostex TC-generator. We have developed an ad hoc teaching strategy that we intend to describe in terms of a number of more or less consistent translating routines later.

From the very start we tried to establish direct links with the world of professional subtitling. We found considerable divergences in the different approaches. Such divergent views, corroborated in a useful account of the state of the art by J. Ivarsson (1992) Subtitling for the Media, are often based on ad hoc grounds and entrenched practice. We therefore invited experienced subtitlers and editors from the BRTN (the Belgian Dutch-speaking television network) to give introductory lectures and even more importantly to evaluate the students' tasks at the end of the course. Our students translate from two foreign languages into Dutch, which is the target language in this part of the world. While visiting foreign students translate into their mother-tongues, we refuse to translate into foreign languages for obvious reasons. In order to avoid pedagogical patchwork the teaching staff agreed to adopt BRTN's subtitling "instructions" (latest update 13.10.92) as a standard. This does not imply that we dispensed altogether with instructions used in other networks. When VTM (the Flemish commercial network) started broadcasting we also inquired about their instructions, and NOB (Dutch Television) have been most helpful in providing material. For all that, we eventually decided to carry on with a single-standard approach, i.e. following the essence of BRTN's instructions, for the sake of consistency. Moreover, BRTN have been involved in relevant eye-movement research with Prof. G. d'Ydewalle's Department at Louvain University for many years now. And finally, we have come to the conclusion that students are perhaps best able to meet the diverging requirements after developing a strategy of their own. Nevertheless divergency remains a moot point in any teaching process. A student of ours, K. Fleurinck (1993) has conducted more detailed research on the matter for her degree paper, tentatively called A Contribution to a Common Standard in Subtitling Instructions

\section{ON-THE-JOB-TRAINING AT THE GHENT INTERNATIONAL FILM FESTIVAL}

Students who finish the subtitling course are offered the opportunity of participating in an inspiring activity at the annual Film Festival. The East-Flemish educational authorities, who sponsor the Ghent Festival, committed themselves in 1990, assuming that our students 
would subtitle foreign films free of charge. Fortunately, they also committed themselves to buying new subtitling equipment if some of the teaching staff agreed to monitor the event. Many students joined us, because it was a unique opportunity for them to spend their compulsory on-the-job-training period in a live subtitling experiment. It has been going on for three years now. At the 1992 Festival twenty-two films were subtitled involving forty-four students.

We proceed as follows. Teams of two students subtitle a film by means of videotaped copies at the College studio. We then take our computers to the theatres in order to project the subtitles. Budget and time constraints do not allow the Festival to have regular subtitled copies made. Since the films are shown only once or twice, exceptionally three times, during the ten-day Festival, the organisers can by no means afford to have over one hundred (mostly new) films translated by professionals, particularly since it is hard to tell which film will make it to the distribution circuit. Only anticipated box-office successes or business-sponsored films are subtitled by regular firms. The rest would remain untranslated if it were not for the trainees, who do the translations and attend each showing. The video subtitles have to be spotted (i.e. displayed) live during the showing, because videotapes and film reels run at different speeds: 25 and 24 frames a second, respectively. Students use a remote keying device to project them manually onto a strip of white canvas underneath the big screen via a BARCO data projector, supplied by BARCO Electronics, who are also sponsors of the Festival. It takes some practice to spot the subtitles to a steady rhythm that matches the dialogues, but the result is most rewarding. The viewers are offered the slightly more elaborate television subtitles, centred below the big screen in $20 \mathrm{~cm}$-characters, instead of the regular cinema subtitles in $30 \mathrm{~cm}$-characters. Informal inquiries with members of the audience indicate that legibility is quite satisfactory provided the subtitles are projected strictly in the same plane as the big screen. Projecting onto the cinema screen itself is not recommendable.

Obviously, professional subtitling firms could hardly be expected to supply this elaborate service at the regular rates, which the Festival could not afford anyway; hence, the reassuring thought that the students are not undercutting their future colleagues. Under the circumstances there are no alternatives: it is either this type of experimental subtitling or no translations at all. Film fans have come to appreciate the students' contribution.

\section{ERASMUS}

In no time subtitling became very popular at the PHVT-College. Over a hundred students have been taking the course this year, including some twenty Erasmus grantees from several universities in Britain, France, Germany and Spain. Foreign students in particular seem to discover a new world of communication, which may be less valued in their major-language countries.

This was brought home to us at a workshop on subtitling at EXPO'92 in Seville, organized on behalf of the Province of East-Flanders. Our Spanish Erasmus alumni from the universities of Seville and Valencia appeared to have turned into keen advocates of subtitling. However, the arguments that subtitling is indeed ten times cheaper and much faster than dubbing, or that it enables viewers not only to watch foreign actors but also to hear them in their native tongues, did not persuade everybody. Major-language countries, such as Spain, are generally dubbing-prone and perceive subtitles as a constraint, i.e. viewers have to read them after all. Viewers in subtitling-prone countries are more lenient. On the whole The Subs and Dubs Divide (R. Dean 1987) is presumably a matter of prejudice and habit. Younger and/or educated viewers seem to be more sensitive to the constraints of the existing subtitling conventions. Is this because of the strictly time-related reading constraint, which offers viewers roughly eleven characters a second regardless of the informative 
density of the message? Hence a potential reticence? And does reading less than what is "auditorily available in another language" trigger cognitive dissatisfaction ?

Luk Warlop (1986) was very cautious of speculations about Who reads what and why? when investigating eye movement.

And so were G. d'Ydewalle et al. (1987), who came to a number of tentative conclusions, some of which have induced us to make a few -hopefully- reasonable assumptions of our own in an attempt to set up a workable canonical format of the subtitle, merely for teaching purposes.

\section{A SUBTITLE FORMAT}

1. The six-seconds rule is "the rule of thumb of most TV stations" and seems to perform best in many respects. (G. d'Ydewalle et al. 1987)

2. Habit seems to be a powerful factor in subtitling. It is a useful notion when considering that subtitles are known to be "un mal nécessaire". Offering them in a consistent format that matches the discourse might make them less conspicuous and thus enhance habituation.

3. Average latency $(0.35 \mathrm{sec}$.) in perception seems to make two-line subtitles possibly less demanding of the viewer than e.g. two successive one-liners, which require two onsets. Consequently the overall "reading time" in two-liners seems to offer the viewer more "reading comfort" ("our terms"). Reading comfort is introduced here, to include the conventional term "readability", which basically refers to lexico-syntactic complexity and does not normally include the physical notion of "granting reading time". Needless to say, our ad hoc, preference for two-liners will require continuous qualification in terms of both the auditory discourse (dialogue) and the visual discourse (cinematographic imperatives).

4. By the same token we ask students to fill up the time-coded translating slots consistently on the assumption that it is more likely to trigger a steadier reading rhythm, which may in turn make reading less conspicuous. Moreover, there is the viewers' suspicion that subtitlers "do not translate everything" anyway (Mark de Neve 1985). It is hoped that this may contribute to redeeming that cognitive dissatisfaction as well.

Summing up, we propose a canonical subtitle format to our students, not for the sake of axiomatic reference but as a guiding principle. And finally, there is still the crucial question to be raised whether an alternative trial-and-error approach would have been more effective.

\section{UNIQUE TRANSLATING CONDITIONS}

Subtitles differ from any other type of translation in various ways. The spoken SL is divided into conventional stretches of 1.5 to maximum 6 seconds, which are rendered proportionally in a maximum of two lines of written TL. The translation can be read on screen for exactly as long as the corresponding utterance can be heard. Consequently, comprehension involves two skills simultaneously: active TL reading and passive SL listening, even if the viewer does not understand SL. The latter then serves as a potential time reference and a prosodic marker. This combination of reading and (even nondeliberate) listening creates a unique situation. This dual discourse is even extended by a third dimension, which consists of relevant auditory and visual information that is not translated. Combined with the fixed subtitle format, all these constraints give rise to at least three acute translating problems, which are probably most typical of subtitling.

Firstly, reductions are inevitable. But reducing the source text by an average of 25 to 50 per cent (J. Ivarsson 1992) is bound to delete information that might well be relevant. Hence the idea that subtitles remain frustratingly "incomplete". Secondly, a corollary is 
the problem of readability. Inexperienced subtitlers tend to produce telegraphese, or complex nominalisations in an attempt to cram in all the information. Thirdly, written subtitles should be made to "sound" like their spoken equivalents. The ultimate question raised, then, is: what sort of equivalence is aimed at in subtitles after all?

Clearly, equivalence in our approach cannot be considered in K. Van Leuven-Zwart's (1992) strict terms. Rather it is a combination of "three levels of equivalence", which are inevitably discourse-related and ideally add up to the closest possible written approximation of the spoken SL utterance.

\section{THREE LEVELS OF EQUIVALENCE}

Erik Ros (1990) compared the NOB and the BRTN-version of part three of the BBC series A Very British Coup investigating the three levels: the informative, the semantic and the communicative, asking very specific questions.

1. Informative equivalence

Has all the information been transferred to the TL?

Compare $(1 a, b):(1 b)$ has transferred more.

(1) I have to tell the House (a) that the Foreign Secretary (b) has this morning tendered his resignation (c) and I have accepted it (d)".

heeft vanmorgen ontslag (c) genomen.

Ik heb het ontslag (c) van de minister van buitenlandse zaken (b) aanvaard (d).

2. Semantic Equivalence

Has the meaning been transferred correctly?

Compare (2a,b). Both omit relevant <INFO >: (2a) (?"claim to") and (2b) (?"working") people.

(2) But this is a government that claims to be in touch with the working people of this country.

(2a) Maar deze regering ?heeft juist

' $\mathrm{n}$ goeie band met de arbeiders.

(2b) Deze regering zegt te weten

wat er bij het ?volk leeft.

3. Communicative Equivalence

Does the subtitle also transfer the "communicative dynamism" (R. Quirk et al. 1985) as reflected in the prosody of the SL utterance? We suggest that this may well be the reason why both our students and FIT-members at a Ghent meeting unanimously preferred (3b) below:

(3) There was \nothing in Tom Newsome's / file to indicate a selcurity risk.

(3a) Er stond niets over Newsome en "n veiligheidsrisico".

(3b) Er was bij Newsome geen \sprake van 'n / veiligheids $\backslash$ risico".

Summing up, it would seem that (3a) and (3b) are comparably equivalent to (3) at level 1 (the informative) and 2 (the semantic). But at level 3 (the communicative) the b-version is heard to sound "better", "more idiomatic", "more natural", etc. It is our suggestion that the reason might well be that there is a communicative "added" value to $(3 b)$, derived from the prosodic properties translated in (3b) but not in (3a). 


\section{TRANSLATING ROUTINES}

At this point, we deliberately disregard the preliminary technicalities involving positioning, cueing time codes, etc., because these are skills that students familiar with word-processing acquire quite rapidly when practising. Trial-and-error and the operator's manual as a rule complete the introductory group sessions very effectively. More acute problems arise when it comes to filling the time-coded translation slots with subtitles. After determining a canonical format for the subtitle and three levels of equivalence to be aimed at, we would like to describe next a set of ad hoc translating routines that seem to work reasonably well when producing subtitles along these lines. Routines are not rules, but guidelines for the translator to handle the SL message in a consistent way in an attempt to increase TL cohesion. There is no suggestion that there are no alternatives, nor that all students and staff adhere to them in exactly the same way. We proceed as follows.

We assume that the sentence is best suited to match the subtitle format for several reasons. It is a syntactic structure in its own right. It comprises essential references to the discourse and sentence elements with syntactic functions $(S, V, O, \ldots)$, semantic roles (agent, instrument, ...), "pragmatic functions: (topicality and focality)" and "prosodic properties" (S.C. Dik, 1989). The latter are very important for achieving communicative equivalence as in (3b). Furthermore, the sentence is to our knowledge the highest syntactic level where English and Dutch carry language-specific differences (e.g. word order) that are particularly relevant. And finally, its format can be more readily adapted to the format of the subtitle, in extreme cases even, for example, as a sequence of right-branching clauses. The linear presentation of the routines below is not intended to reflect a strict sequence in time. The routines are only meant as an auxiliary device to be used in case the students' translation process short-circuits in complex environments, or so-called "literal translations".

1. The $<\mathrm{INFO}>$ And $<$ MARK $>$ Routines

We first check the $<$ INFO $>$ rmation structure of the SL message and try to locate the topical and focal area(s).

Simultaneously we check (i.e. listen) whether any sentence elements are $<$ MARK $>$ ed for prominence in S.C. Dik's sense (1989: 39), i.e. with reference to "dominant clause order", and/or to the dominant nuclear stress. Most utterances are un $<$ MARK $>$ ed, of course. e.g. $(1,2)$. But reconsider (3)

(3) [There was \nothing in Tom Newsome's / file to [indicate] a se \curity risk.]

(3a) Er| stond $\left.\right|^{P 1}$ niets over Newsome en

'n veiligheidsrisico"' $\left.0\right|^{\mathrm{P} 2}$

(3b) $\quad \mathrm{Er} \mid$ was $\left.\right|^{\mathrm{P} 1}$ bij Newsome geen $\mid \backslash$ sprake $\left.\right|^{\mathrm{P} 2}$ van

"n / veiligheids \risico".

The [topical area] and the [focal area] of (3) seem to "overlap" (S.C Dik's term 1989) in the $<\mathrm{V}>$ erb indicate. The existential "There"-clause highlights nothing in extraposition and se $\backslash$ curity risk carries a neutral nuclear stress. Both subtitlers $(3 a, b)$ have tried to transfer the information content, while apparently preserving both the <INFO>structure and the pragmatic structure marked by the prosody. In order to realize the translation we next proceed with $<$ SOV $>$ routines.

2. The $<$ SOV $>$ Routines

We consider Dutch as an SOV-language in our approach, because of its "bipolar" (discontinuous) verb phrase which divides Dutch clause structure into two basic types (ANS 1985). More importantly, this characteristic also seems to determine the rhythm of Dutch, which is quite distinct from the stress-timed rhythm of 
English. Rhythm irrefutably contains an element of consistency, which the reading of subtitles can only benefit from. Therefore, we try to underpin the rhythmic pattern from the onset, by introducing an early first "pole" in the Dutch sentence, depending entirely on the $<\mathrm{INFO}>$ structure, of course.

We then try to insert the bulk of the (new) information in the mid-field before the second verb "pole". Hence there is some reticence about transferring long initial English subjects as such into Dutch. Compare (4) with $(4 a, b)$ :

(4) The recommendations of every department are for a / State of E\mergency, Prime Minister. (The system is really at breaking point.)

aan, (de instorting is nabij.)

(4b) Alle ministeries $\mid$ raden $\left.\right|^{\mathrm{Pl}}$ aan om de ınoodtoestand af te kondigen.

Our first $<$ SOV $>$ routine, is the $<$ S $>$ routine. That is to say, we look for a suitable $<$ S $>$ ubject in the topical area. As can be seen in $(4 a, b)$, it need not necessarily be the same, provided it does not unduly disturb the semantic equivalence. What matters in $(4 \mathrm{a}, \mathrm{b})$ is that a long English $\langle\mathrm{S}\rangle$ is reduced in that position. While doing so, we avoid modifying the SL $<\mathrm{INFO}>$ structure, preferring to adapt the TL syntactic structure to match it. A very typical solution is the Dutch "frame-setting" $<\mathrm{iA}>$, which stands for "initial Adverbial". We always invite students to try an $<i A>$ routine to transfer part of a massive English $<\mathrm{S}>$. Another typical case is the English "instrumental" $\langle\mathrm{S}\rangle$ that will be turned into a fully-fledged initial Dutch Adverbial $<i A>$ :

"/This knife won't \open it." will most likely be translated as

"Met / dit mes krijg je dat niet \open"

The (alternative) $\langle\mathrm{S}\rangle$ will require a suitable $\langle\mathrm{V}\rangle$, which is "openkrijgen" in (5a), and so on, till all the relevant $<\mathrm{INFO}>$ has been transferred. The "dummy" $<\mathrm{S}>j e$ in (5a) may seem a deviation from SL, but it enhances the readability of the TL-structure. A reduced version might well be:

"/ Hiermee $\backslash$ lukt het niet."

3. The $<$ CONV>erting Routines

This is the umbrella term borrowed from computer science to refer to a host of manipulations that have been called "des transpositions et des modulations" ( $\mathrm{H}$. Chuquet and M. Paillard, 1989), or "vertaaltransformaties" (A. Langeveld 1991), and many other names. We make no attempt to list all the possible combinations. For our purpose $3 .<\mathrm{CONV}>$ erting even covers swapping $<$ ACT $>$ ives and $<$ PAS $>$ sives, when meaningful. We try to induce the student to develop a $<\mathrm{CONV}>$ erting awareness of his own while preserving the $S L<I N F O>$ structure. It is hoped that this will also help him find the appropriate TL sentence structures before completing them with lexical equivalents from dictionaries and other sources. We refer to the latter routines as the $<$ EQUI > valent <SYNO>nym and <ANTO>nym routines ( $\mathrm{H}$. Brondeel, 1992).

We might sum up with sample (4b), where part of the long English $<S>$ recommendation is $\langle\mathrm{CONV}>$ verted into $\langle\mathrm{V}\rangle$ aanraden, moving the first $\langle\mathrm{V}\rangle$-pole closer up front, which is a more frequent position in a comparable Dutch structure. 
4. <MAT> routines (Modality, Aspect and Tense) are next in our discussion, which does not mean in the order of application.

Translators usually tackle $<$ MAT $>$ when they come to deal with the $<\mathrm{V}>$ erb. Our approach introduces $\langle\mathrm{MAT}>$ as soon as the potential $\mathrm{TL}\langle\mathrm{V}\rangle$ has been spotted during the $<\mathrm{INFO}>$ and $<\mathrm{MARK}>$ routines. Incidentally, the time constraint on subtitles is often detrimental to the transfer of $<$ ASPECT $>$. There seems to be a convention in Dutch subtitling to reduce verb phrases rather unduly to the simple tense forms, for obvious reasons; however, the viewers seem to have become accustomed to this deviant tense usage.

5. Four Syntactic Routines

It would again be inappropriate to relate the introduction of these routines to a sequence in time. Complex SL $<\mathrm{INFO}>$ structures, for example, will immediately call for potential $<$ REDU $>$ ctions, which is the most frequently used of the four routines that deal more explicitly with the syntactic complexity of the message.

The $<$ REDU $>$ ction routine basically serves to compress the $<$ INFO $>$ to match the subtitle format. It usually operates in combination with $<\mathrm{CONV}>$ routines, again with due respect for the $<$ INFO $>$ structure.

The $<$ EXPA $>$ nsion routine helps to compensate for the lack of lexical substance in a position that deserves more structural "weight" in R. Quirk et al's terms (1985). It is hardly necessary to mention that it is unlikely to be used frequently in subtitling.

The $<$ SEGM $>$ entation routine provides for additional pauses in (long, and particularly, complex) SL messages. It splits them up into smaller <INFO > units and is often combined with a fourth syntactic routine, which affects the hierarchy of the sentence structure.

The $<$ REOR $>$ dering routine is instrumental in reordering the interdependency of syntactic structures (usually at clause level) in order to enhance readability, e.g. by eliminating nesting, frequent left-branching, or by simply re-coordinating previously $<\mathrm{SEGM}>$ ented clauses, etc.

We do not attempt to offer our students exhaustive descriptions of all the possible combinations. What we do try to bring home is the overall process of transferring the SL messages, via their $<\mathrm{INFO}>$ structures and in the same "communicative order", by adapting the (reduced) TL structures accordingly, so as to offer the viewer reliable and idiomatic equivalents.

A visual representation might look like this:

Section 1. contains the SL message in SVO-order

Section 2. has <INFO $>$ and $<$ MARK $>$ routines that "filter" the SL message, allowing the essence to reach

Section 3. where the (often reduced SOV-) equivalent TL-structures are realized.

In order to do so we use the appropriate routines as represented on the two superimposed rotating discs. The larger disc contains the $<$ function $>$ routines $(\mathrm{S}, \mathrm{V}, \mathrm{O}, \ldots)$ and the four $<$ syntactic $>$ routines $(<$ SEGM $>,<$ REDU $>,<$ EXPA $>$ and $<$ REOR $>$ ). By rotating the disc they can affect any part of section 3 . The smaller disc carries the $<M A T>$ and $<\mathrm{CONV}>$ routines, which manipulate sentence elements at all levels often in combination with other routines. 


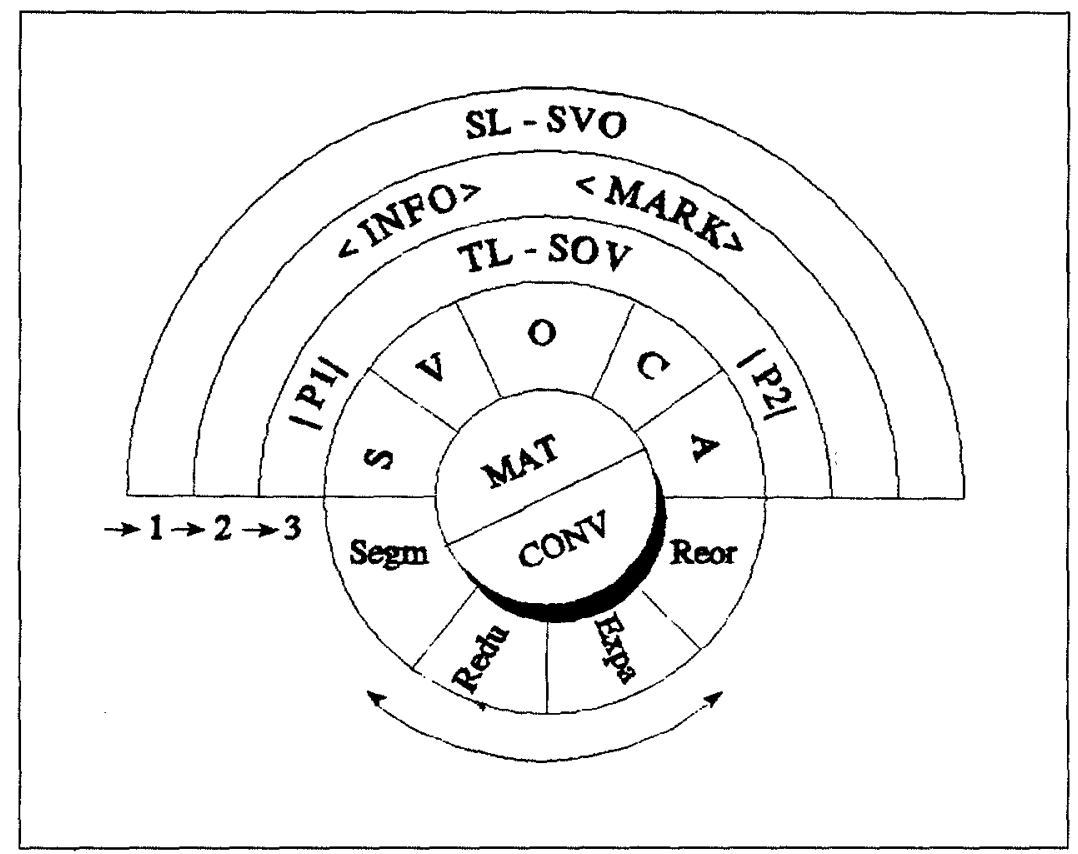

\section{REFERENCES}

BRONDEEL, H. (1992): Vertaalroutines PHVT-syllabus.

CHUQUET, $H$. and M. PAILLARD (1989): Approche linguistique des problèmes de traduction AnglaisFrançais, Paris, Ophrys.

D'YDEWALLE, G., VAN RENSBERGEN, J. and J. POLLET (1987): "Reading a Message When the Same Message is Available Auditorily in Another Language: The Case of Subtitling" In O'Regan, J.K.O. and A. Lévy-Schoen Ed., Eye Movements: From Physiology to Cognition. Amsterdam/New York, pp. 313-321.

DEAN, R. (1987): "The Subs and Dubs Divide", TV World. (International Business magazine for TV and video), London, Vol X, No 5, pp. 38-39.

DE NEVE, M. (1985): “En bovendien vertalen ze niet alles" In Taalbeheersing 1985, pp. 1018-29.

DEWANCKEL, Leen (1991): Reduction in the Dutch and Flemish Subtitles of A VERY BRITISH COUP (PHVT, Ghent unpublished).

DIK, S. C. (1989): The Theory of Functional Grammar Dordrecht, Foris Publications.

FLEURINCK, K. (1993): A Contribution to a Common Standard in Subtitling Instructions (PHVT, Ghent unpublished).

IVARSSON, J. (1992): Subtitling for the Media Stockholm, Transedit.

LANGEVELD, A. (1986): Vertalen wat er staat Amsterdam, Arbeiderspers.

QUIRK, R. et al. (1985): A Comprehensive Grammar of the English Language Longman.

REID, Helen (1977): "Subtitling, the Intelligent Solution" In Translating, a Profession Proceedings of the VIII World Congress, International Federation of Translators, Ed. Horguelin P., Montréal, pp. 420-28.

ROS, Erik (1991): Informative, Semantic and Communicative Equivalence in Subtitles NOB and BRT Subtitles to Part Three of A VERY BRITISH COUP compared (PHVT, Ghent unpublished).

VAN LEUVEN-ZWART, K. (1992): Vertaalwetenschap: ontwikkelingen en perspectieven Muiderberg, Coutinho WARLOP, L. (1986): Ondertitels: wie leest wat en waarom? Oogbewegingsonderzoek naar de aandachtsverdeling bij ondertitelde televisieprogramma's Brussels, Belgium: Belgian Radio and Television Research Department. 